\title{
Analisis Kelembagaan Pengelolaan Zakat Dan Fungsi Sosial Perbankan Syariah
}

\author{
P. Adiyes Putra; Nurnasrina \\ Sekolah Tinggi Agama Islam Diniyah Pekanbaru; UIN Suska Riau \\ Adiyes.putra123@gmail.com; nurnasrina@uin-suska.ac.id
}

\begin{abstract}
Institutional zakat in Islamic banking has been regulated in Article 4 Paragraph 2 of Law No. 21 of 2008 concerning Islamic Banking. Where in that article Islamic banks are allowed to perform social functions in the form of collecting zakat, donations, alms, grants, or other social funds. The activities of Islamic banks conducting social activities become additional activities for Islamic banks. In contrast to the main function of Islamic banks as an intermediary function such as the collection and distribution of public funds that are required for Islamic banks to do so, while the social functions of Islamic banks only written in the Islamic banking Act can run, meaning that Islamic banks can choose between performing social functions or not doing it. The uncertainty of the Sharia Banking Law in regulating social functions makes Islamic banks not full of seriousness in carrying out these social functions. The lack of seriousness of this Islamic bank can be seen from the 14 Sharia Commercial Banks (BUS), only 10 BUSs that carry out social functions, and there are still 4 BUSs that have not yet performed social functions. The total funds that have been successfully collected and utilized by 10 BUS in the last 2 years are in 2017 Islamic banks collect zakat funds of Rp. 76.7 billion or $1.23 \%$ of the total funds raised by BAZNAS and LAZ (Rp. 6.22 trillion). In 2018 the collection of zakat funds through BUS experienced an increase of $16 \%$ from 2017 or collected Rp. 88.9 billion or $1.1 \%$ of the total zakat funds raised by BAZNAS and LAZ (Rp. 8.1 trillion). When compared to the amount of zakat fund raised by this BUS with the potential for national zakat totaling Rp. 217 Trillions, of course the achievement is not up to $1 \%$, this means that the collection of zakat funds by the BUS is still far from expectations.
\end{abstract}

Keywords: Zakat Institution, Social Function, Zakat, Islamic Bank

\section{Pendahuluan}

Perbankan syariah sebagai industri keuangan syariah memiliki kekhasan jika dibandingkan dengan bank konvensional. Selain memiliki fungsi intermediasi, bank syariah juga memiliki fungsi sosial. Fungsi sosial dimaksudkan, bank syariah dibolehkan menghimpun dana-dana sosial umat seperti zakat, infaq, sedekah, hibah, dan wakaf serta menyalurkannya kepada organisasi pengelola zakat. Fungsi sosial bank syariah ini tertuang dalam Undang-Undang Nomor 21 Tahun 2008 tentang 
Perbankan Syariah (selanjutnya disebut UU No. 21 Tahun 2008 tentang Perbankan Syariah) pada pasal 4 ayat 2 menyatakan bahwa: "Bank syariah dan UUS dapat menjalankan fungsi sosial dalam bentuk lembaga baitul mal, yaitu menerima dana yang berasal dari zakat, infaq, sedekah, hibah, atau dana sosial lainnya dan menyalurkannya kepada organisasi pengelola zakat". ${ }^{1}$

Berdasarkan pasal 4 ayat 2 UU No. 21 Tahun 2008 Tentang Perbankan Syariah ini, fungsi perbankan syariah mengalami perluasan yaitu bank sebagai "lembaga amil zakat". Bank sebagai penghimpun zakat memunculkan konstruksi hukum kelembagaan pengelolaan zakat mengalami perkembangan melalui pengelolaan zakat berkonsep perusahaan. Bank syariah sebagai perusahaan memiliki kantor cabang sudah lebih dari 2.251 kantor $^{2}$ dan telah memiliki sistem yang terkoneksi dan telah terbukti aman menjadi alternatif model dalam penjaringan dan pengelolaan zakat. Bank syariah sebagai pengelola zakat diharapkan mampu mendorong peningkatan jumlah dana zakat yang dihimpun. Akan tetapi kedudukan perbankan syariah dalam penghimpunan dana zakat sejak disyahkannya UU Perbankan Syariah Tahun 2008 sampai sekarang masih menjadi problem yuridis bagi perbankan syariah.

Problem yuridis dapat dilihat berdasarkan ketentuan Pasal 7 ayat 2 UndangUndang Nomor 23 Tahun 2011 Tentang Pengelolaan Zakat, yang menyebutkan bahwa dalam melaksanakan tugas dan fungsinya Badan Amil Zakat Nasional (BAZNAS) dapat bekerja sama dengan pihak terkait sesuai dengan ketentuan peraturan perundang-undangan. Dalam Pasal 7 ini memperlihatkan bahwa peran perbankan syariah sebagai lembaga penghimpun zakat belum disebutkan secara kongkrit. Masalah ini menimbulkan berbagai masalah normatif dalam regulasi pengelolaan zakat di Indonesia. ${ }^{3}$

\footnotetext{
${ }^{1}$ Nurnasrina dan P. Adiyes Putra, Kegiatan Usaha Bank Syariah (Jogyakarta: Kalimedia, 2018), 250

${ }^{2}$ Otoritas Jasa Keuangan (OJK) RI, Statxistik Perbankan Syariah, Mei 2019,

3 Aristoni, "Problematika Peran Perbankan Syariah Dalam Regulasi Kelembagaan Pengelolaan Zakat”, Jurnal Ziswaf, 5(1), Juni 2018, 115
} 
Menurut Ahmad Dakhoir, problem yuridis dalam undang-undang Nomor 23 Tahun 2011 Tentang Pengelolaan Zakat memasukan Pasal 7 ayat 2, memunculkan kekosongan norma dalam fungsi sosial bank syariah. Kekosongan norma terlihat dalam 2 substansi; substansi pertama, bahwa fungsi sosial bank syariah sebagai lembaga bait al-mal dalam Pasal 4 ayat 2 UU Nomor 21 Tahun 2008 Tentang Perbankan Syariah, tidak diakui sebagai lembaga penerima zakat sebagaimana Pasal 7 ayat 2 UU Nomor 23 Tahun 2011 Tentang Pengelolaan Zakat. ${ }^{4}$ Hal ini bertolak belakang dengan UU Nomor 38 Tahun 1999 Tentang Pengelolaan Zakat yang mengakui eksistensi perbankan dalam membantu pengumpulan zakat (meskipun hanya dalam zakat harta dan bank umum konvensional). ${ }^{5}$ Substansi kedua, bahwa kekosongan norma terlihat dengan belum diaturnya peraturanperaturan pelaksana yang digunakan sebagai pedoman teknis pengelolaan zakat melalui perbankan syariah. ${ }^{6}$

Berikutnya dalam UU Nomor 21 Tahun 2008 Tentang Perbankan Syariah, Pasal 4 ayat 2 kata "dapat menjalankan fungsi sosial dalam bentuk lembaga baitul mal" merupakan dalam bentuk pilihan, yaitu boleh menjalankan peran sosial atau tidak. Ketidak tegasan dalam mengamanahkan bankan syariah untuk memaksimalkan fungsi peran sosial tersebut berdampak pada tidak semua bank syariah menerapkannya. Meskipun ada bank syariah yang menerapkan peran sosial tersebut tetapi belum dikelola secara transparan dan akuntabel. Beberapa bank syariah bahkan mencampur-adukkan antara dana zakat dengan dana Corporate Social Responsibility (CSR), sehingga dikhawatirkan pengelolaan dan

\footnotetext{
${ }^{4}$ Bunyi Pasal 7 ayat 2 UU Nomor 23 Tahun 2011 Tentang Pengelolaan Zakat, Dalam Melaksanakan Tugas dan Fungsinya, BAZNAS dapat Bekerja Sama dengan Pihak terkait Sesuai dengan Ketentuan Peraturan Perundang-undangan.

${ }^{5}$ Bunyi Pasal 12 ayat 2 UU No.38 Tahun 1999 Tentang Pengelolaan Zakat, "Badan Amil Zakat dapat Bekerja Sama dengan Bank dalam Pengumpulan Zakat Harta Muzakki yang Berada di Bank atas Permintaan Muzakki”.

${ }^{6}$ Ahmad Dakhoir, Hukum Zakat; Pengaturan Integrasi Kelembagaan Pengelola Zakat Dengan Fungsi Lembaga Perbankan Syariah (Surabaya: Aswaja Presindo, 2015), 19
} 
pendistribusian dana zakat bank dan nasabahnya tidak sesuai dengan syariat Islam. ${ }^{7}$ Sebagaimana diketahui bahwa syariat Islam tentang zakat sangat jelas, baik dari aspek pengumpulannya maupun pendistribusiannya. Menurut Indah Purbasari dkk, menjelaskan bahwa dalam prakteknya bank syariah lebih mempublikasikan dana tanggung jawab sosial perusahaan, meskipun di dalamnya terdapat dana zakat. ${ }^{8}$ Permasalahan ini dipicu oleh dua tanggung jawab yang harus dilaksanakan oleh perbankan syariah, yaitu sebagai perusahaan yang harus tunduk dengan UndangUndang Nomor 40 tahun 2007 tentang Perseroan Terbatas (PT) yang mengatur kewajiban PT mengalokasikan dana tanggung jawab sosial perusahaan. Di sisi lain perbankan syariah juga diamanahkan untuk mengumpulkan dana zakat perusahaan dan karyawan sesuai dengan UU No. 21 Tahun $2008 .^{9}$

\section{Metode Penelitian}

Dalam penelitian ini jenis penelitian yang dilakukan tergolong pada penelitian hukum normatif. Penelitian jenis ini menurut Soerjono Soekanto dan Sri Mamudji disebut juga dengan penelitian perpustakaan. Disebut penelitian perpustakaan dikarenakan metode atau cara yang dipergunakan di dalam penelitian hukum yang dilakukan dengan cara meneliti bahan yang tersedia pada perpustakaan. ${ }^{10}$ Sedangkan metode penelitiannya menggunakan metode penelitian kualitatif. Metode ini didasarkan atas analisis yang dilakukan terhadap UU No. 21 Tahun 2008 tentang Perbankan Syariah dan UU No. 23 Tahun 2011 tentang Pengelolaan Zakat serta peraturan pemerintah lainnya yang berhubungan dengan kelembagaan pengelolaan zakat.

\footnotetext{
${ }^{7}$ Nikmatul Masruroh, "Zakat di Perbankan Syariah”. Jurnal al-Mashraf. 2(1). Oktober 2015, 33.

${ }^{8}$ Indah Purbasari, dkk., Alokasi, Distribusi dan Dana Tanggung Jawab Sosial di Perbankan Syariah dalam Masalah-masalah Hukum, Jilid 44 No.2 April 2015, 140.

${ }^{9}$ Indah Purbasari, dkk., Alokasi, Distribusi dan Dana Tanggung Jawab Sosial ...,,141

10 Soerjono Soekanto dan Sri Mamudji, Penelitian Hukum Normatif Suatu Tinjauan Singkat (Jakarta: Raja Grafindo Persada), 13-14.
} 


\section{Hasil dan Diskusi}

Zakat merupakan perintah Allah SWT yang diwajibkan kepada umat Islam untuk mengeluarkan sebagian hartanya kepada hasnaf yang delapan. Kewajiban zakat ini adalah ajaran Islam yang mengajarkan kepedulian kepada sesama, tidak mencintai harta secara berlebihan, dan wujud kecintaan kepada Allah SWT. Ibadah zakat agak berbeda dengan ibadah lain seperti sholat, puasa dan haji yang hanya bersifat ibadah belaka (mahdhah), tapi ibadah zakat selain ibadah murni juga merupakan ibadah yang berdimensi penciptaan kesejahteraan ekonomi dan keuangan. Dimensi ini begitu kentara dengan adanya konsep berbagi (distribusi kekayaan) pada zakat, dimana orang yang mempunyai kelebihan harta menyisihkan sebagian dari hartanya untuk orang-orang fakir, orang miskin, hamba sahaya dan lain sebagainya. Islam memberikan posisi kegiatan ekonomi menjadi salah satu aspek penting untuk mendapatkan kebahagiaan, sebab kegiatan ekonomi tidak berbeda sebagaimana tujuan syariat islam itu sendiri (maqasid asy-syari'ah) yaitu untuk mendapatkan kebahagiaan di dunia dan akhirat. ${ }^{11}$

Kalau dicermati dengan seksama, kewajiban zakat ini adalah bagi semua umat Islam yang memiliki harta yang telah sampai nisab dan haulnya. Di Indonesia berdasarkan data sensus penduduk tahun 2010, penganut Islam berjumlah \pm 207 juta jiwa atau 87,18\% dari 238 juta jiwa penduduk Indonesia. ${ }^{12}$ Jumlah ini adalah yang mayoritas di dunia. Jumlah penduduk yang besar tentulah tersimpan potensi yang besar juga khususnya dalam penghimpunan zakat. Berdasarkan data jumlah potensi zakat Indonesia berjumlah Rp. 217 Triliyun, jumlah ini akan terus bertambah seiring makin baiknya tingkat pertumbuhan ekonomi masyarakat.

Potensi zakat yang besar jika dikelola dengan baik akan menjadi salah satu sumber pendapatan negara yang potensial. Negara akan dapat terbantu khususnya dalam mensejahterakan masyarakat yang kurang mampu. Dalam melakukan

\footnotetext{
${ }^{11}$ Fira Mubayyinah. "Ekonomi Islam Dalam Perspektif Maqasid Asy-Syariah”. Journal of Sharia Economics. 1(1). 2019, 14-29.

${ }^{12}$ Website Wikipedia, Islam di Indonesia, https://id.wikipedia.org/wiki/Islam_di_Indonesia, diakses pada Hari Kamis, 5 Maret 2020 pukul 22.10 WIB
} 
pengelolaan zakat yang besar itu diperlukan sistem manajerial administrasi yang baik, sistem pembukuan keuangan yang akuntabel, sumber daya insani (pengelola zakat) yang profesional dan jujur, dan sistem hukum yang kuat. Selain itu juga diperlukan sokongan penuh dari pemerintah, hal ini mengingat zakat bukan hanya masalah kedermawanan dan keikhlasan dalam menjalankan ibadah zakat, tapi juga menyangkut tindakan otoritatif (kekuatan memaksa) dari pemerintah terhadap orang-orang yang enggan untuk membayar zakat.

Sistem pengelolaan zakat seperti di atas tentulah tidak muncul dengan tibatiba, dibutuhkan proses dan waktu untuk mewujudkannya. Proses pengelolaan zakat di Indonesia melewati jalan yang panjang seperti yang telah dijelaskan pada bagian awal pada bab ini. Pengelolaan zakat baru memiliki kekuatan hukum ketika telah disahkannya UU No. 38 tahun 1999 tentang Pengelolaan Zakat. Pengesahan UU ini dilakukan ketika zaman telah berganti, zaman Orde Baru di bawah kepemimpinan Presiden Soeharto digantikan oleh Zaman Reformasi di bawah Presiden BJ. Habibie. Usulan RUU tentang Pengelolaan Zakat yang diajukan oleh Departemen Agama atas desakan umat Islam diterima oleh Presiden BJ. Habibie dan untuk kemudian disahkan oleh DPR RI lewat sidang paripurna DPR.

Pengesahan UU No. 38 tahun 1999 ini menjadi landasan yuridis formal dalam menjalankan pengelolaan zakat. Tapi meskipun telah memiliki kekuatan hukum yang kuat, masih tetap belum mampu mendongkrak pertumbuhan pengumpulan dan penyaluran dana zakat. Secara konstitusi UU No. 38 tahun 1999 masih memiliki kelemahan-kelemahan yang pada kemudian hari dilakukanlah revisi terhadap UU tersebut, sehingga melahirkan UU No. 23 Tahun 2011 tentang Pengelolaan Zakat.

Dalam UU No. 23 tahun 2011 tentang Pengelolaan Zakat dijelaskan bahwa yang dimaksud dengan pengelolaan zakat adalah kegiatan perencanaan, pelaksanaan, dan pengoordinasian dalam pengumpulan, pendistribusian, dan pendayagunaan zakat. Kegiatan perencanaan diawali dengan membuat program, budgeting, pendataan muzakki dan mustahiq, penghimpunan (funding), pengorganisasian meliputi struktur pengelola zakat, pemilihan amil yang tepat dan penentuan layanan yang mudah diakses. Pengelolaan juga harus ditunjang dengan 
perangkat yang memadai, kemudian dilakukan dengan tindakan nyata melakukan sosialisasi serta pembinaan kepada muzakki maupun mustahiq, dan melakukan pengawasan dari sisi kesesuaian syariah, manajemen pengelolaan, dan keuangan. ${ }^{13}$

Menurut Yusuf Qardhawi, pengelolaan zakat mutlah dilakukan oleh pemerintah melalui suatu lembaga khusus yang memiliki sistem manajemen yang fungsional dan profesional. Hal ini dimaksudkan untuk mencapai hasil yang optimal dan efektif. Lebih lanjut ia mengemukakan bahwa zakat merupakan sumber pertama dan utama bagi perbendaharaan Islam dalam mengentaskan kemiskinan. Lebih lanjut Qadhawi menawarkan konsep pengelolaan zakat yang dapat digolongkan dalam dua pendekatan, yakni; pertama; pendekatan struktural (institusional) yaitu suatu lembaga yang dibentuk khusus mengurusi masalah zakat, kedua; dari segi operasional, bahwa pengelolaan zakat untuk memberdayakan ekonomi umat dapat dilakukan dengan sistem investasi yaitu dana zakat dapat digunakan untuk mendirikan unit-unit usaha / UKM untuk menyediakan pekerjaan bagi dhu'afa sehingga mempunyai sumber penghidupan yang wajar. ${ }^{14}$

Peran pemerintah dalam pengelolaan zakat sebetulnya telah dicontohkan sejak Nabi Muhammad SAW menjadi kepala negara dan kepala pemerintahan. Nabi menunjuk para sahabat yang tidak diragukan integritas dan kejujurannya dalam mengelola zakat. Beliau juga melakukan tindakan tegas kepada umat yang enggan untuk membayar zakat. Penunjukan orang yang dapat dipercaya dan menindak tegas orang yang tidak mau membayar zakat mampu mendongkrak pendapatan zakat. Kebijakan yang dilakukan Nabi ini kemudian tetap diteruskan oleh khalifah Islam setelahnya, baik masa Abu Bakar, Umar bin Khatab, Ustman bin 'Affan dan Ali bin Abi Tholib. Para khalifah tersebut terus melakukan penguatan lembaga pengelola zakat khususnya penguatan baitul mal dan melakukan tindakan tegas kepada umat yang tidak mau membayar zakat.

Kebijakan-kebijakan yang telah diambil oleh Khalifah Islam di atas juga terus diperkuat oleh kekhalifahan Islam setelahnya, baik pada masa kekhalifahan Bani

\footnotetext{
${ }^{13}$ Ahmad Dakhoir, Hukum Zakat..., 28

${ }^{14}$ Yusuf Qardhawi dalam Ahmad Dukhoir, Hukum Zakat..., 28
} 
Umayyah (41-132 H/661-750 M), Bani Abbasiyah (131- 640 H/749-1258 M), maupun kekhalifahan Turki Utsmani (672-1306 H/1290-1924M). Tercatat dalam sejarah kekhalifahan Islam puncak kejayaan pengelolaan zakat terjadi ketika pada masa Khalifah Umar Bin Abdul Azis (99-101 H/717-719 M). Umar bin Abdul Azis adalah seorang khalifah yang sangat populis, bijak, tegas serta disiplin. Ia pun tidak segan untuk memecat pejabat yang terbukti korup pada masa itu. Diantara kebijakan dan kebajikannnya yang cukup terkenal adalah melakukan reformasi dalam bidang ekonomi khususnya penataan pengelolaan zakat. Baitul mal sebagai lembaga yang ditunjuk untuk mengelola zakat diperkuat kedudukannya dan bersikap tegas kepada pembangkang zakat serta melakukan penyaluran zakat kepada mereka yang berhak menerima zakat. Tindakan penguatan lembaga zakat yang dilakukan khalifah Umar bin Abdul Azis ini menuai hasil, tercatat selama periode kekhalifahannya sangat susah para mustahiq yang berhak menerima zakat untuk ditemukan. Artinya ini mengindikasikan bahwa tidak ada orang miskin pada zaman itu, dan masyarakat hidup dengan tingkat kesejahteraan yang sudah cukup tinggi. $^{15}$

Keberhasilan Khalifah Umar bin Abdul Azis dalam meningkatkan kesejahteraan masyarakat di atas diawali dengan melakukan reformasi pengelolaan zakat. Reformasi pengelolaan zakat dimulai dengan melakukan perbaikan terhadap sistem kelembagaan zakat. Kelembagaan zakat menyangkut aturan yang menjadi landasan hukum penerapan zakat, manajerial pengelolaannya, organisasi pengelola zakat, sistem penghimpunan dan penyaluran zakat dan lain sebagainya, termasuk juga perbaikan terhadap komponen-komponen yang menyusun kelembagaan zakat.

\footnotetext{
15 Website Republika, Teladan Khalifah Umar bin Abdul Azis dalam Pengelolaan Zakat, https://www.republika.co.id/berita/dunia-islam/islam-digest/16/10/01/oecz7r313-teladan-khalifahumar-bin-abdul-aziz-dalam-pengelolaan-zakat. Dan lihat juga web gomuslim, Baznas Terinspirasi Khalifah Umar bin Abdul Azis dalam Mengelola Zakat, https://www.gomuslim.co.id/read/news/2016/06/11/629/baznas-terinspirasi-kholifah-umar-binabdul-aziz-dalam-mengelola-zakat.html. Diakses pada Hari Jum'at, 6 Maret 2020 Pukul 9.30 WIB,
} 
Di Indonesia, salah satu komponen kelembagaan zakat yang penting untuk menjadi perhatian adalah menyangkut persoalan amil. Amil adalah badan pengelola atau organisasi pengelola zakat. Menurut Pasal 1 poin 7 UU No. 23 tahun 2011 tentang Pengelolaan Zakat, bahwa Badan Amil Zakat Nasional (BAZNAS) adalah lembaga yang melakukan pengelolaan zakat secara nasional. Poin berikutnya disebutkan Lembaga Amil Zakat (LAZ) adalah lembaga yang dibentuk oleh masyarakat yang memiliki tugas pengumpulan, pendistribusian, dan pendayagunaan zakat, serta Unit Pengumpul Zakat (UPZ) adalah satuan organisasi yang dibentuk oleh BAZNAS untuk membantu pengumpulan zakat. ${ }^{16}$

BAZNAS sebagai amil zakat secara nasional diatur dalam Keputusan Presiden Republik Indonesia Nomor 8 Tahun 2001 tentang Badan Amil Zakat Nasional. Pasal 4 dalam KEPPRES ini mengatur tugas BAZNAS, yaitu melaksanakan pengelolaan zakat sesuai dengan peraturan perundang-undangan yang berlaku dan menyampaikan laporan hasil pelaksanaan tugasnya setiap tahun kepada Presiden dan DPR. Tugas BAZNAS ini kemudian dipertegas lewat pasal 6 UU No. 23 tahun 2011 tentang Pengelolaan Zakat, yaitu BAZNAS merupakan lembaga negara yang berwenang melakukan tugas pengelolaan zakat secara nasional. Dalam menjalankan tugas tersebut, BAZNAS boleh membentuk UPZ di lembaga-lembaga pemerintahan, lembaga BUMN/BUMD, lembaga swasta, dan lembaga lainnya, begitu juga BAZNAS dibolehkan melakukan kerjasama dengan pihak terkait berdasarkan ketentuan perundang-undangan. Selain itu dalam membantu tugas BAZNAS dalam pengumpulan, pendistribusian, dan pendayagunaan zakat, masyarakat diperbolehkan membentuk LAZ.

Terkait dengan BAZNAS, UPZ dan LAZ sebagai amil zakat menjadi perhatian serius dalam pengelolaan zakat karena amil merupakan perantara antara muzakki dengan mustahiq. Peran amil sebagai perantara tidaklah bisa dikecilkan karena peran amil cukuplah penting, yaitu menyatukan orang yang kelebihan dana dengan orang yang memerlukan dana. Amil bertindak sebagai pihak ketiga. Sebagai

${ }^{16}$ Pasal 1 UU No. 23 tahun 2011 tentang Pengelolaan Zakat, 
pihak ketiga, amil harus benar-benar mampu dan bisa bertanggung jawab kepada semua pihak termasuk kepada pemerintah.

Menyangkut persoalan amil, disini perlu dijelaskan terlebih dahulu maksud dari pada amil. Kata amil berasal dari bahasa arab 'amil atau bentuk jamaknya 'amiliin yang berarti bekerja, lengkapnya kata 'amil adalah al-'amiliina 'alayha yaitu orang atau sekelompok orang yang secara aktif bekerja atau bertugas melakukan pengelolaan zakat dalam konteknya yang mendasar, umum dan luas. Kata al'amiliina 'alayha terdapat dalam Al Qur'an Surat Ali Imran [3]: 195, dan QS. At-Taubah [9]: 60. Meskipun secara redaksional ahli tafsir, hadits dan fikih berbeda pendapat tentang makna kata ini, namun secara substantif mereka sepemikiran bahwa yang dimaksud dengan 'al'amiliina 'alayha adalah orang atau sekelompok orang yang melaksanakn tugas dan tanggung jawab dalam pengelolaan zakat. Ada juga yang memaknainya dengan para penghimpun atau pengelola zakat, juru tulis, penjaga, distributor, dan tokoh/pimpinan kelompok dan lain-lain. ${ }^{17}$ Menurut Yusuf Qordhawi dalam fiqih zakatnya ia mengemukakan bahwa yang dimaksud amil dalam kontek zakat adalah orang yang bekerja dan terlibat secara langsung maupun tidak langsung dalam hal pengelolaan zakat. Jika yang mengelola adalah lembaga, maka semua orang yang bekerja di lembaga itu disebut amil, baik itu direktur, dan para pegawainya, asalkan mereka dapat gaji dari bagian amil. ${ }^{18}$

Sementara itu empat Imam Mazhab memiliki beberapa perbedaan dalam menjelaskan tentang amil tapi tidak begitu signifikan. Imam Syafe'i mendefenisikan amil adalah orang yang bekerja mengurusi zakat, dan tidak mendapatkan upah selain dari jatah amil dari zakat tersebut. Artinya menurut Imam Syafe'i, amil termasuk ke dalam salah satu hasnaf yang berhak mendapatkan bagian dari zakat yang dihimpun. Imam Abu Hanifah memberikan defenisi tentang amil, yakni orang yang diangkat untuk mengambil dan mengurus zakat. Sedangkan Imam

\footnotetext{
${ }^{17}$ Muhammad Mahmud Hijazi dalam Muhammad Amin Suma, Sinergi Fikih dan Hukum Zakat Dari Zaman Klasik Hingga Kontemporer (Ciputat: Kolam Publising, 2019), 207-208

${ }^{18}$ Yusuf Qordhawi, Fiqih Zakat cetakan ke-24 (Bairut: Muassasatu Ar-Risalah, 1997), 121
} 
Hambali mengartikan amil zakat adalah pengurus zakat yang diberi zakat atau upah atas pekerjaanya. ${ }^{19}$

Senada dengan pendapat empat Imam Mazhab di atas, Majelis Ulama Indonesia (MUI) melalui komisi fatwa, merumuskan tentang amil zakat. Amil zakat adalah pertama; seseorangan atau kelompok orang yang diangkat oleh pemerintah untuk mengelola pelaksanaan ibadah zakat, kedua; seseorang atau sekelompok orang yang dibentuk oleh masyarakat dan disahkan oleh pemerintah untuk mengelola pelaksanaan ibadah zakat. Rumusan Komisi Fatwa MUI ini menyesuaikan dengan amil yang dimaksud dalam UU Pengelolaan Zakat. Apa yang dirumuskan MUI tentang amil zakat ini mendatangkan kritik dari penggiat zakat, menurut mereka persyaratan "diangkat" oleh pemerintah maupun "yang disahkan oleh pemerintah" ini tidak dikenal sebelumnya karena jauh sebelum UU Pengelolaan Zakat disahkan oleh pemerintah, di masyarakat telah banyak amil zakat yang dibentuk tanpa ada pengesahan dari pemerintah. ${ }^{20}$

Memperhatikan masukan terhadap pendapat komisi fatwa MUI di atas, MUI terus melakukan kajian dan diskursus, sehingga melahirkan Fatwa MUI Nomor 8 Tahun 2011 tentang Amil Zakat. dalam fatwa itu MUI menetapkan syarat-syarat yang harus dipenuhi oleh seorang amil zakat, diantaranya; Beragama Islam, mukallaf (berakal dan baligh), amanah, dan memiliki ilmu pengetahuan tentang hukum-hukum zakat dan hal lain yang terkait dengan tugas amil zakat. ${ }^{21}$ Hampir sama dengan ini, Abdul Hamid Mahmud al-Ba'li juga mengemukakan syarat-syarat untuk menjadi amil zakat, diantaranya; amanah, adil, pandai menghitung dan menakar zakat, berakhlak baik, memiliki pemahaman yang mendalam tentang zakat, tidak aniaya dan tidak menerima hadiah apalagi ryswah (suap). ${ }^{22}$

Sementara itu dalam UU No. 23 Tahun 2011 tentang Pengelolaan Zakat disebutkan syarat-syarat yang harus dipenuhi oleh seseorang yang akan menjadi

\footnotetext{
${ }^{19}$ Ahmad Dukhoir, Hukum Zakat..., 30

${ }^{20}$ Muhammad Amin Suma, Sinergi Fikih..., 209

${ }^{21}$ Fatwa MUI No.8 Tahun 2011 tentang Amil Zakat

${ }^{22}$ Abdul Hamid Mahmud, dalam Muhammad Amin Suma, Sinergi Fikih..., 218
} 
amil zakat nasional atau yang akan menjadi anggota BAZNAS. Syarat-syarat itu adalah sebagai berikut;

a) Warga Negara Indonesia

b) Beragama Islam

c) Bertaqwa kepada Allah SWT

d) Berakhlak mulia

e) Berusia paling sedikit 40 tahun

f) Sehat jasmani dan rohani

g) Tidak menjadi anggota partai politik

h) Memiliki kompetensi di bidang pengelolaan zakat

i) Tidak pernah dihukum karena melakukan tindakan pidana kejahatan yang diancam dengan pidana penjaca paling sedikit 5 (lima) tahun. ${ }^{23}$

Seterusnya setelah amil zakat memenuhi syarat-syarat yang telah ditetapkan dalam UU Pengelolaan Zakat, amil zakat melakukan tugas dan tanggung jawabnya sebagai amil. Adapun tugas amil zakat adalah sebagai berikut;

a. Penarikan/pengumpulan zakat yang meliputi pendataan wajib zakat, penentuan objek wajib zakat, besaran nishab zakat, besaran tarif zakat, dan syarat-syarat tertentu pada masing-masing objek wajib zakat;

b. Pemeliharaan zakat yang meliputi inventarisasi harta, pemeliharaan, serta pengamanan harta zakat; dan

c. Pendistribusian zakat yang meliputi penyaluran harta zakat agar sampai kepada mustahiq zakat secara baik dan benar, dan termasuk pelaporan. $^{24}$

Serupa dengan tugas dalam fatwa MUI di atas, Muhamamad Amin Suma juga mengemukakan bahwa tugas amil zakat sebelum melakukan peghimpunan,

${ }^{23}$ Pasal 11 UU No. 23 tahun 2011 tentang Pengelolaan Zakat

${ }^{24}$ Fatwa MUI No.8 Tahun 2011 tentang Amil Zakat 
pendistribusian dan pelaporan dana zakat terlebih dahulu harus melakukan mengkoordinasikan perumusan perencanaan penghimpunan dana zakat, atau membuat rencana anggaran pendapatan berikut rencana pendistribusiannya dengan baik dan benar. ${ }^{25}$

Berangkat dari pengertian amil, syarat-syarat menjadi amil dan tugas serta kewajiban amil zakat di atas, dapat dipahami bahwa keberadaan amil zakat adalah sesuatu yang teramat penting, mengingat amil zakat adalah orang atau lembaga yang menghubungkan antara muzakki dengan mustahiq zakat. Mengingat pentingnya peran amil zakat, maka harus dikelola secara profesional, amanah, jujur, transparan dan akuntabel demi terciptanya kelembagaan pengelola zakat yang dipercaya oleh masyarakat.

Kelembagaan pengelolaan zakat seperti yang dibahas pada bagian atas tulisan ini telah memiliki landasan hukum yang kuat berdasarkan UU No. 23 Tahun 2011 tentang Pengelolaan Zakat. Berdasarkan UU ini pengelolaan zakat digawangi oleh BAZNAS, dan LAZ. Dua lembaga ini diperbolehkan untuk melakukan kerjasama dengan lembaga terkait yang tidak bertentangan dengan peraturan perundangundangan yang berlaku. Penjelasan tentang ketentuan dapat bekerjasama, dijelaskan bahwa BAZNAS dan LAZ bisa bekerjasama dengan lembaga-lembaga baik lembaga pemerintah, lembaga swasta, perusahaan milik pemerintah (BUMN/BUMD), lembaga luar negeri dan lain sebagainya. Melakukan kerjasama dengan lembaga-lembaga bisa dilakukan dengan membuka UPZ-UPZ disetiap lembaga-lembaga atau menganjurkan lembaga-lembaga yang ada membentuk LAZ sendiri.

Salah satu lembaga yang sangat potensial untuk diajak bekerjasama adalah perbankan syariah. Perbankan syariah merupakan bagian dari sektor jasa keuangan yang dalam aktivitasnya, khususnya produk, akad dan layanannya, selain bertumpu pada prinsip kehati-hatian (prudential banking principles) juga wajib mematuhi

${ }^{25}$ Muhammad Amin Suma, Sinergi Fikih..., 220 
prinsip syariah. ${ }^{26}$ Perbankan syariah memiliki kegiatan usaha berhubungan dengan bisnis keuangan, dengan kegiatan utamanya menghimpun dana (funding), menyalurkan dana (lending), memiliki jasa-jasa bank (service) dan kegiatan sosial. Kegiatan menghimpun, menyalurkan dan jasa bank memiliki kemiripan dengan dengan bank secara umum, tapi kegiatan sosial adalah kekhasan bank syariah yang tidak dimiliki oleh bank konvensional. Menurut Pasal 4 UU No. 21 Tahun 2008 tentang Perbankan Syariah, bank syariah memiliki beberapa fungsi, diantaranya; pertama; bank syariah dan UUS wajib menjalankan fungsi menghimpun dan menyalurkan dana masyarakat, kedua; bank syariah dan UUS dapat menjalankan fungsi sosial dalam bentuk lembaga baitul mal, yaitu menerima dana yang berasal dari zakat, infak, sedekah, hibah, atau dana sosial lainnya dan menyalurkannya kepada organisasi pengelola zakat, ketiga; bank syariah dan UUS dapat menghimpun dana sosial yang berasal dari wakaf uang dan menyalurkannya kepada pengelola wakaf (nazhir) sesuai dengan kehendak pemberi wakaf (wakif), keempat; pelaksanaan fungsi sosial sebagaimana dimaksud pada poin dua dan tiga sesuai dengan ketentuan peraturan perundang-undangan. ${ }^{27}$

Memperhatikan fungsi bank syariah di atas, terlihat bahwa fungsi pertama merupakan fungsi inti yang harus dijalankan oleh yang namanya bank baik bank syariah maupun bank konvensional. Sedangkan fungsi kedua dan ketiga merupakan fungsi tambahan yang harus dijalankan oleh bank syariah. Fungsi sosial seperti yang tertera dalam UU No. 21 tahun 2008 tentang Perbankan Syariah menjelaskan fungsi sosial dapat dijalankan oleh bank syariah dalam bentuk baitul mal, dalam menghimpun dan menyalurkan dana sosial seperti zakat. Meskipun dalam UU itu menuliskan dengan kata "dapat menjalankan" yang berarti boleh memilih antara melakukan dengan tidak melakukan fungsi sosial, tapi secara fungsi bank syariah telah diperkenankan menjalankan fungsi sosial tersebut. Fungsi sosial yang dijalankan bank syariah menandakan terjadinya perluasan makna kegiatan bank

${ }^{26}$ Rachmad Nor Firman. "Laju Percepatan Perkembangan Perbankan Syariah Melalui Penerapan Tata Kelola Syariah". Journal of Sharia Economics. 1(2). 2019, 165-182.

${ }^{27}$ Pasal 4 UU No.21 Tahun 2008 tentang Perbankan Syariah 
syariah dari yang hanya berfungsi sebagai penghimpun dana dan menyalurkan dana, bertambah dengan fungsi sosial bank syariah.

Fungsi sosial bank syariah dijalankan dalam bentuk lembaga baitul mal. Terkait dengan baitul mal dapat dijelaskan bahwa lembaga ini telah ada sejak zaman Nabi Muhammad SAW. Pendirian baitul mal yang dilakukan pada zaman Nabi dilatar belakangi oleh percekcokan para sahabat Nabi SAW dalam pembagian harta rampasan Perang Badar. Percekcokan antar sahabat menjadi asbabun nizul turunnya firman Allah SWT berikut;

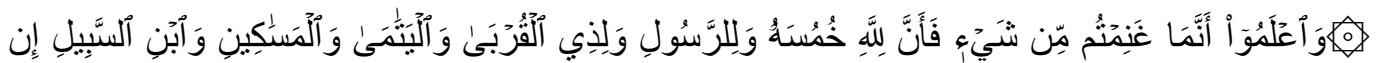

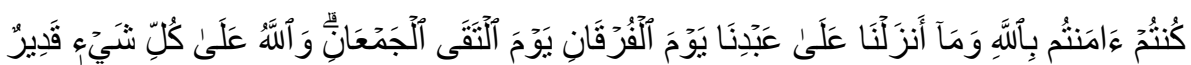

Artinya: "Ketahuilah, sesungguhnya apa saja yang dapat kamu peroleh sebagai rampasan perang, maka sesungguhnya seperlima untuk Allah, Rasul, kerabat Rasul, anak-anak yatim, orang-orang miskin dan ibnussabil, jika kamu beriman kepada Allah dan kepada apa yang kami turunkan kepada hamba Kami (Muhammad) di hari Furqaan, yaitu di hari bertemunya dua pasukan. Dan Allah Maha Kuasa atas segala sesuatu”. (QS. Al-Anfal [8]: 41)

Setelah turunnya ayat 8 Surat Al-Anfal ini, Rasulullah kemudian memprakarsai berdirinya baitul mal. Baitul mal pada masa Rasul bertugas mengatur masalah ghonimah, khorroj, jizyah, zakat, dan masalah pendapatan dan belanja negara (APBN). Dengan tugas yang diemban oleh lembaga baitul mal, menjadikan lembaga ini memegang peranan yang sangat vital dalam menggerakan perekonomian dan pemerintahan Islam yang baru berdiri di bawah kepemimpinan Rasululullah SAW. Meskipun keberadaan baitul mal pada masa Nabi telah memegang peranan vital tapi pengelolaanya masih sangat sederhana. Harta benda dikelola belum melewati pencatatan yang rapi, sehingga ketika ada harta benda yang masuk langsung dibagi-bagikan kepada kaum muslimin yang berhak menerimanya, atau ada juga sebagian yang digunakan untuk keperluan umum dan membiayai peperangan melawan kafir Quaisy.

Perbaikan pengelolaan baitul mal dilakukan pada masa Khalifah Abu Bakar Siddiq, khalifah melakukan penguatan fungsi baitul mal. Semua sumber-sumber pendapatan negara dikelola oleh baitul mal, adapun sumber-sumber itu adalah berasal dari zakat, wakaf, jizyah, kharraj, $f a ' i$, dan sumber-sumber lainnya. 
Pengumpulan sumber-sumber ini telah disiapkan tempatnya di Masjid Nabawi dengan seorang petugas khusus yang ditunjuk khalifah bernama Abu Ubaidah bin Jarrah. Tempat pengumpulan baitul mal tidak hanya berasal dari ghonimah, jizyah atau khorroj tapi juga dipenuhi oleh harta zakat, infak, sedekah dan wakaf. Pada masa Khalifah Abu Bakar pengumpulan zakat memang menjadi perhatian serius karena seiring munculnya golongan pembangkang terhadap zakat. Khalifah mengambil tindakan tegas dengan cara memerangi orang-orang yang tidak mau membayar zakat. Ketegasan khalifah ini membuat orang yang sudah mulai enggan untuk membayar, mau untuk kembali membayar zakat, sehingga gudang tempat penyimpanan harta negara kembali terisi.

Gudang-gudang penyimpanan baitul mal terus bertambah ketika Umar bin Kattab naik menjadi khalifah. Khalifah dengan gencar melakukan perluasan wilayah kekuasaan Islam seperti ke Kisra Persia, Qaishar Romawi dan daerah lain dibagian Utara Afrika. Perkembangan wilayah ini memberikan pengaruh terhadap pertumbuhan ekonomi dengan banyaknya pendapatan negara yang mengalir ke Madinah. Peningkatan jumlah harta yang terhimpun di baitul mal, membuat khalifah makin melakukan penguatan terhadap baitul mal. Khalifah membangun ad-diwan (kantor) khusus baitul mal di daerah-daerah yang telah dikuasai, mengangkat para penulis zakat, menetapkan gaji pengelola baitul mal dan membangun angkatan perang yang lebih modern.

Upaya di atas diteruskan oleh Khalifah Ustman bin Affan, khalifah melakukan penguatan dan merapikan sistem yang ada pada baitul mal. Upaya penguatan juga dilakukan pada masa Khalifah Ali bin Abi Tholib, dengan sikapnya yang terkenal profesional, sistem akuntabilitas dalam operasionalisasi pengelolaan harta benda negara. Sistem pengelolaan baitul mal pada masa khalifah-khalifah di atas menunjukan pengelolaannya dilakukan secara bertanggung jawab dan penuh kehati-hatian, sehingga pengelola baitul mal begitu dipercayai oleh umat Islam pada masa itu. Kondisi ini agak berubah setelah Bani Umayyah, Bani Abbasiyah dan Kerajaan-kerajan Islam lainnya berkuasa. Al-Maududi mengemukakan, “jika pada masa sebelumnya baitul mal dikelola dengan penuh kehati-hatian sebagai amanah Allah SWT dan amanah rakyat, maka pada masa pemerintahan Bani Umayyah 
baitul mal berada sepenuhnya di bawah kekuasaan khalifah tanpa dapat dipertanyakan atau dikritik oleh rakyat". ${ }^{28}$

Terlepas dari pengelolaan baitul mal yang agak buruk pada masa-masa kekhalifahan Islam sepeninggal Khalifah Urrasyidin, yang disebabkan oleh penyimpangan-penyimpangan yang terjadi, baitul mal telah menjadi bagian terpenting dalam sejarah peradaban Islam. Tercatat baitul mal telah menjadi lembaga negara yang berfungsi sebagai pengelola keuangan negara selama berabad-abad lamanya, hingga runtuhnya kekhalifahan Islam Utsmani di Turki tahun $1924 \mathrm{M}$.

Setelah kekhalifahan Islam runtuh, istilah baitul mal mengalami pengecilan makna. Hal ini disebabkan oleh makin luasnya dominasi pengaruh bangsa eropa terhadap dunia Islam. Istilah-istilah keislaman sengaja diganti dengan istilah-istilah kebarat-baratan, termasuk lembaga-lembaga yang berbau keislaman diganti dengan lembaga-lembaga yang dikelola hanya untuk kepentingan bangsa eropa. Eropa melakukan penjajahan besar-besaran terhadap wilayah-wilayah yang dahulu dikuasai oleh Islam, seperti yang terjadi di Asia dan Afrika. Di daerah yang mereka kuasai dikembangkanlah tiga misi utama yang kemudian dikenal dengan istilah 3 G, yakni Gold, Gospel dan Glory. ${ }^{29}$

Selain mencari kekayaan dengan memperluas wilayah jajahannya, bangsa eropa juga mengajarkan dan mengembangkan ajaran agama Kristen yang mereka anut ke penduduk daerah yang mereka kuasai. Pengumpulan kekayaan dan peyebaran agama Kristen makin mengkerdilkan peran baitul mal. Dari segi ekonomi tugas baitul mal yang selama kekhalifahan dan kerajaan Islam menjadi

\footnotetext{
${ }^{28}$ Al-Maududi dalam Ahmad Dukhoir, Hukum Zakat..., 73

${ }^{29}$ Misi 3G (Gold, Glory, dan Gospel) adalah motivasi bangsa barat dalam melakukan perjalanannya. 1. Gold, mendorong bangsa barat untuk memburu kekayaan berupa emas, perak, dan barang berharga lainnya. 2. Glory, artinya kejayaan. Bangsa barat percaya bahwa kejayaan sebuah bangsa dilihat dari seberapa banyak daerah kekuasaannya. 3. Gospel, bangsa barat tidak hanya mencari harta dan kejayaan saja, tapi mereka juga menyebarluaskan ajaran injil. Simak lebih lanjut di Brainly.co.id - https://brainly.co.id/tugas/13435069\#readmore
} 
lembaga mengelola keuangan untuk kemajuan perekonomian, dikuasai oleh bangsa barat. Kekayaan negara dan sumber-sumber pemasukan negara diambil alih oleh barat. Penguasaan bangsa barat ini tidak membuat lembaga baitul mal bisa bergerak leluasa, bahkan disebagian negara Islam lembaga baitul mal hanya tinggal nama seperti yang terjadi di hampir seluruh daerah di Indonesia. Meskipun ada disebagian daerah, baitul mal hanya sekedar mengumpulkan zakat fitrah, dan zakat mal, itupun pengelolaannya hanya ala kadarnya yang dijalankan oleh pengurus masjid/musholla, yayasan panti asuhan dan anak yatim, lembaga pendidikan dan lain sebagainya. Kesemua lembaga-lembaga ini melakukan pengumpulan zakat, infak, sedekah dan wakaf hanya sekedar menjembatani orang untuk menunaikan kewajiban agama, dan kemudian dipergunakan untuk keperluan yang ada dilingkungan lembaga tersebut. Kecilnya ruang lingkup kerja dan wewenang lembaga-lembaga itu membuat mereka tidak berani menamakan dirinya sebagai lembaga baitul mal. Meskipun ada baitul mal, hanya diartikan sebagai lembaga penghimpun dana dari zakat, infak, sedekah, wakaf, hibah dan dana-dana lainnya untuk kemudian disalurkan kepada yang berhak menerimanya.

Kondisi di atas telah berlangsung lama, hingga sekarangpun lembaga baitul mal masih diartikan sebagaimana di atas. Pengertian baitul mal masih mengalami pengecilan makna dan belum bisa menyamai makna seperti yang ada pada masa Nabi dan Kekhalifahan Islam setelahnya. Begitu juga yang terjadi dengan fungsi sosial yang dimaksud dalam UU No. 21 tahun 2008 tentang Perbankan Syariah. Dalam pasal 4 poin 2 dinyatakan bahwa "Bank Syariah dan UUS dapat menjalankan fungsi sosial dalam bentuk lembaga baitul mal, yaitu menerima dana yang berasal dari zakat, infak, sedekah, hibah, atau dana sosial lainnya dan menyalurkannya kepada organisasi pengelola zakat".

Kalau dicermati dari segi bahasa dalam UU di atas, fungsi sosial yang dijalankan oleh bank syariah merupakan tugas tambahan. Tugas tambahan berfungsi sebagai lembaga baitul mal. Berdasarkan redaksional bahasa dari UU tersebut kata "dapat menjalankan" menunjukkan bahwa perbankan syariah hanya berfungsi sosial, bukan berfungsi sebagaimana fungsi utamanya sebagai intermediasi menghimpun dan menyalurkan dana masyarakat. Fungsi intermediasi dibunyikan dalam pasal 4 ayat 1 UU No. 21 tahun 2008 tentang Perbankan Syariah 
dengan menggunakan kalimat "wajib menjalankan”. Kalimat ini menunjukkan keharusan bank syariah untuk menjalankan kegiatan usahanya yang berhubungan dengan penghimpunan dan penyaluran dana, jika tidak menjalankan fungsi ini, maka bank syariah tidak bisa lagi disebut sebagai bank. Berbeda halnya dengan fungsi sosial yang dimaksud diatas, ketika bank syariah tidak menjalankan fungsi sosial, maka tidak menggugurkan fungsi-fungsi bank yang lainnya.

Berikutnya kata "baitul mal", secara normatif tidak dijelaskan pengertiannya dalam UU No. 21 tahun 2008 tentang Perbankan Syariah. Begitu juga dalam UU No. 23 tahun 2011 tentang Pengelolaan Zakat, juga tidak ada dijumpai kata "baitul mal”. Kata baitul mal baru dijumpai pada penjelasan UU No. 23 tahun 2011 tentang Pengelolaan Zakat pasal 15 ayat 1 yang berbunyi "Di Provinsi Aceh, penyebutan BAZNAS provinsi atau BAZNAS kabupaten/kota dapat menggunakan istilah baitul mal'. Pengistilahan yang disebutkan dalam penjelasan ini hanya berlaku untuk BAZNAS yang ada di Provinsi Aceh, dan ini tidak berlaku pada provinsi lainnya. Meskipun terdapat kata baitul mal dalam penjelasan UU ini, tapi tidak menjelaskan secara gamblang pengertian dari baitul mal itu sendiri.

Melihat ketiadaan pengertian baitul mal dalam 2 UU tersebut, maka secara perspektif normatif telah terjadi kekosongan norma. Akibat kekosongan norma tersebut menyebabkan adanya ketidakpastian hukum yag disebabkan oleh ketidakpastian aturan. Makanya ketika kepastian aturan tidak ada, bank syariah dalam menjalankan fungsi sosialnya tidak dapat dipaksa seperti pemaksaan dalam menjalan fungsi intermediasi.

Ketidakpastian juga terlihat dari redaksi organisasi pengelolaan zakat, menurut pasal 4 ayat 2 UU No. 21 tahun 2008 tentang Perbankan Syariah disebutkan bahwa penyaluran zakat dana yang dihimpun lewat lembaga baitul mal disalurkan kepada organisasi pengelola zakat. Mengenai organisasi pengelola zakat seperti yang terdapat dalam UU No. 23 tahun 2011 tentang Pengelolaan Zakat disebutkan bahwa organisasi pengelola zakat yang diakui menurut UU adalah BAZNAS, dan LAZ. Jika dicermati dari kedua UU ini tentang organisasi pengelola zakat yang dimaksud, maka terjadi pertentangan asas, norma dan kaedah penyaluran zakat antara pasal 4 ayat 2 UU No. 21 tentang Perbankan Syariah 
dengan fungsi dan peran BAZNAS dalam UU No. 23 tahun 2011 tentang Pengelolaan Zakat. Pertentangan asas, norma dan kaedah dalam penyaluran zakat ini menyebabkan bank-bank syariah lebih suka menyalurkan dana zakat yang telah dihimpunnya kepada organisasi zakat yang dibentuk sendiri oleh bank syariah tersebut dan hanya bagian kecil saja dana zakat itu disalurkan oleh bank syariah kepada BAZNAS.

Memperhatikan hal-hal di atas khususnya dalam ketidakpastian aturan dalam fungsi sosial bank syariah, fungsi tambahan yang dijalankan bank syariah sebetulnya memiliki peran yang strategis dalam melakukan penjaringan dana zakat dan dapat pula sebagai model pengelolaan zakat secara tepat guna, terpadu, modern dengan sistem yang canggih dan rapi. Akan tetapi peran besar itu justru tidak diakui secara eksplisit dalam UU No. 23 tahun 2011 tentang Pengelolaan Zakat. Tidak adanya pengakuan tersebut mengakibatkan kekaburan fungsi sosial pada bank syariah. Kekaburan fungsi sosial ini menunjukkan peran dan fungsi sosial perbankan syariah menjadi lemah bahkan tidak diakui sama sekali. Kekaburan fungsi sosial bank syariah ini berdampak pada kurang seriusnya bank syariah melakukan penerapan fungsi sosialnya, hal ini dapat dilihat dari 14 Bank Umum Syariah (BUS) yang ada, hanya 10 BUS yang melaksanakan fungsi sosial, dan masih ada 4 BUS yang belum melaksanakan fungsi sosial. Total dana yang telah berhasil dihimpun dan didayagunakan oleh 10 BUS dalam 2 tahun terakhir adalah tahun 2017 bank syariah mengumpulkan dana zakat sebesar Rp. 76,7 Miliyar atau 1,23\% dari jumlah keseluruhan dana yang dihimpun oleh BAZNAS dan LAZ (Rp. 6.22 Triliyun). Pada tahun 2018 penghimpunan dana zakat lewat BUS pengalami peningkatan sebesar 16\% dari tahun 2017 atau terhimpun sebesar Rp. 88,9 Miliyar atau $1,1 \%$ dari jumlah keseluruhan dana zakat yang dihimpun oleh BAZNAS dan LAZ (Rp. 8,1 Triliyun). Jika dibandingkan besaran pengumpulan dana zakat yang dihimpun oleh BUS ini dengan potensi zakat nasional yang berjumlah Rp. 217 Triliyun, tentu capaiannya tidak sampai $1 \%$, ini artinya pengumpulan dana zakat yang dilakukan BUS masih jauh dari harapan. 


\section{Kesimpulan}

Kelembagaan zakat pada perbankan syariah telah diatur dalam Pasal 4 ayat 2 UU No. 21 Tahun 2008 tentang Perbankan Syariah. Dimana dalam pasal itu bank syariah dibolehkan melakukan fungsi sosial berupa penghimpunan zakat, infak, sedekah, hibah, atau dana sosial lainnya. Kegiatan bank syariah melakukan kegiatan sosial ini menjadi kegiatan tambahan bagi bank syariah. Berbeda dengan fungsi utama bank syariah sebagai fungsi intermediasi seperti penghimpunan dan penyaluran dana masyarakat yang diwajibkan bagi bank syariah untuk melakukannya, sedangkan fungsi sosial bank syariah hanya dituliskan dalam UU perbankan syariah dapat menjalankan, artinya bank syariah dapat memilih antara melakukan fungsi sosial atau tidak melakukannya. Ketidaktegasan UU Perbankan Syariah dalam mengatur fungsi sosial membuat bank syariah tidak penuh keseriusan dalam melaksanakan fungsi sosial tersebut. Ketidakseriusan bank syariah ini dapat dilihat dari tidak semuanya bank syariah menjalankan fungsi sosial, masih ada beberapa bank syariah yang tidak menjalankannya.

Selain itu, bank syariah sebagai organisasi pengelola zakat secara yuridis belum diakui sebagai pengelola zakat yang resmi seperti yang dimaksud dalam UU No. 23 Tahun 2011 tentang Pengelolaan Zakat. Dalam UU ini tidak satupun kata bank syariah disebut sebagai organisasi pengelolan zakat. Tidak adanya kata bank syariah menjadikan pelaksanaan fungsi sosial bank syariah menjadi kososng secara norma hukum. Kekosongan norma ini mendatangkan masalah baru dalam kelembagaan pengelolaan zakat pada perbankan syariah. Oleh karena itu dalam mendorong peran lebih bank syariah dalam penghimpunan, penyaluran dan pendayagunaan dana zakat, maka diperlukan aturan hukum yang sejalur antara aturan yang menjadi pondasi perbankan syariah dengan pengelolaan zakat. Berikutnya diperlukan juga hubungan antar koneksi organisasi pengelolaan zakat dengan komunikasi satu pintu, dimana data based yang ada pada masing-masing organisasi pengelola zakat terkoneksi dengan lembaga-lembaga lain yang berhubungan dengan masalah zakat dan penciptaan kesejahteraan masyarakat. Dan untuk seterusnya dibutuhkan peran serta pemerintah secara menyeluruh terutama melakukan pemaksaan kepada wajib zakat untuk mengeluarkan zakat dari harta miliknya, sebab sebaik dan sebagus apapun organisasi pengelola zakat dibangun 
tapi jika tidak ada penegasan dari pemerintah akan membuat penghimpunan dana zakat sulit untuk ditingkatkan.

\section{Daftar Pustaka}

Aristoni, "Problematika Peran Perbankan Syariah Dalam Regulasi Kelembagaan Pengelolaan Zakat", Jurnal Ziswaf. 5(1). Juni 2018.

Dahlan, Abdul Aziz. Ensiklopedi Hukum Islam, Cetakan II. Jakarta : PT Ichtiar Baru van Hoeve, 1999

Dakhoir, Ahmad. Hukum Zakat; Pengaturan Integrasi Kelembagaan Pengelola Zakat Dengan Fungsi Lembaga Perbankan Syariah. Surabaya: Aswaja Presindo, 2015

Fatwa MUI No.8 Tahun 2011 tentang Amil Zakat

Firman, Rachmad Nor. "Laju Percepatan Perkembangan Perbankan Syariah Melalui Penerapan Tata Kelola Syariah". Journal of Sharia Economics. 1(2). 2019, 165-182.

Maman, Abdul. Hukum Ekonomi Syariah. Jakarta: Kencana, 2012

Mubayyinah, Fira. "Ekonomi Islam Dalam Perspektif Maqasid Asy-Syariah". Journal of Sharia Economics. 1(1). 2019, 14-29.

Nurnasrina dan Putra, P. Adiyes. Kegiatan Usaha Bank Syariah. Jogyakarta, Kalimedia, 2018.

Qordhawi, Yusuf. Fiqih Zakat cetakan ke-24. Bairut: Muassasatu Ar-Risalah, 1997

Summa, Muhammad Amin. Sinergi Fiqih dan Hukum Zakat Dari Zaman Klasik Hingga Kontemporer. Ciputat: Kolam Publising, cet. 1, 2019

UU No. 21 Tahun 2008 tentang Perbankan Syariah

UU No. 23 Tahun 2011 tentang Pengelolaan Zakat

UU No. 38 Tahun 1999 tentang Pengelolaan Zakat

Website Brainly, Misi 3G (Gold, Glory, dan Gospel), https://brainly.co.id/tugas/13435069\#readmore, Akses Pada Hari Selasa, 10 Maret 2020 pukul 21.30 WIB

Website Gomuslim, Baznas Terinspirasi Khalifah Umar bin Abdul Azis dalam Mengelola Zakat, https://www.gomuslim.co.id/read/news/2016/06/11/629/baznasterinspirasi-kholifah-umar-bin-abdul-aziz-dalam-mengelola-zakat.html. Diakses pada Hari Jum'at, 6 Maret 2020 Pukul 9.30 WIB

Website Republika, Teladan Khalifah Umar bin Abdul Azis dalam Pengelolaan Zakat, https://www.republika.co.id/berita/dunia-islam/islamdigest/16/10/01/oecz7r313-teladan-khalifah-umar-bin-abdul-aziz-dalampengelolaan-zakat, Hari Jum'at, 6 Maret 2020 Pukul 9.40 WIB

Website Islam $\quad$ Wikipedia, Indonesia, https://id.wikipedia.org/wiki/Islam_di_Indonesia, diakses pada Hari Kamis, 5 Maret 2020 pukul 22.10 WIB

Website Zakat, https://zakat.or.id/bab-iii-nisab-dan-kadar-zakat/, diakses Hari Kamis, 5 Maret 2020 pukul 21.55 WIB

Zallum, Abdul Qadim. Al-Amwal Fi Daulah Al Khilafah. Cetakan I. Beirut : Darul 'Ilmi Lil Malayin, 1983 